\title{
EMISSIONS OF CARBON MONOXIDE AND SUSPENDED PARTICLES FROM THE STEEL FOUNDRY OF S.C. PROMEX S.A.
}

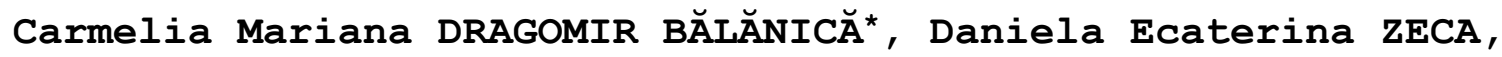 \\ Dorin Grigore EFTIMIE \\ "Dunarea de Jos" University of Galati, Romania \\ e-mail: *cdragomir@ugal.ro
}

\begin{abstract}
The purpose of this article is to analyse the level of pollution of the installations related to the steel foundry operated by S.C. PROMEX S.A. Brăila, activity carried out on site and facilities put into operation, to assess the impact of these activities on the quality of environmental factors, potential risk and measures taken to prevent and reduce pollution. The determination of carbon monoxide $\left(\mathrm{mg} / \mathrm{m}^{3}\right)$ and Suspended particles $\left(\mathrm{mg} / \mathrm{m}^{3}\right)$ was done during 2016-2019.
\end{abstract}

KEYWORDS: air pollution, steel foundry, special steels, potential risk

\section{Introduction}

Environmental impact and usage of energy and equipment are significant issues in industry [1]. The iron and steel industry has an essential part by consuming extremely high materials and energy [2]. In this regard the air pollution is the fundamental significance. The iron and steel industry are the largest industrial sources of $\mathrm{CO}$ and furthermore, the foundry operations produce mineral ashes, acidifying mixtures, products of partial combustion, and volatile organic carbons.

Foundries are a significant component of the iron and steel industry and, consequently, are distinguished by the equivalent energy consumption and environmental issues [3].

Emissions resulting from the rough materials manipulation processes are fugitive particulates produced from receiving, discharging, stowage and transport all materials for the foundry. These emissions are directed by locking up the main pollution sources and directing the air from the chamber within the filter fabric. Emissions include hydrocarbons and contain smoke, organic substances, suspended particles and carbon monoxide (CO) [4].

Metal foundry functions at higher temperatures which has as effect the dispersion of gas into the atmosphere. To study the distinct processes in which pollution can prevail in the metal foundry, it is essential to understand the various processes that exist in the steel foundry [5]. The process executed by a steel foundry may be trippingly underlined as melting, casting and finishing [6].
According to [7] the atmospheric pollutants emitted from metal casting are those resulting mainly from analytical pyrolysis. Pollution control methods has an essential position in environmental protection. Filters, Wet scrubber and Cyclone technique are well known air pollution control methods that must be used in steel foundries to decrease the quantity of noxious emissions that can be dispersed into the atmosphere [8]. Worldwide is being considered air pollution control methods has a critical contribution in reducing the air pollutants [9].

\section{Materials and methods}

The Steel Foundry occupies an area of 28,080 sqm. The foundry is located in the north western part of Brăila (Figure 1). The Steel Foundry is located inside the S.C. PROMEX S.A. Brăila and is surrounded by other production sections: Loading Base, Auto base, Middle Forge and Excavator Factory (in conservation).

In the Steel Foundry section, cast steel semifinished products are produced, from the simplest to the most complex, and the main activity is the processing of ferrous metals - smelters for ferrous metals, with a production capacity of more than 20 tons/day.

Operational processes of the Steel Foundry consist of: Unloading, storage and pneumatic transport of sand, preparation of mixtures for forming, preparing shapes according to patterns, elaboration of alloy and high alloy steels in electric 
arc furnaces, casting of steel molds, debating of forms, cleaning, sandblasting of semi-finished products, heat treatment in the oven with 40 sqm movable hearth, quality control and shipping of semifinished products to the processing sections. The operational processes specific to the special foundry are: development of special steels and cast iron in induction furnaces of $250 \mathrm{~kg}$ each, nodulation and molding of steel. The formed parts reach the drum debater or the main debater, then enter the oxyacetylene cutting (weeding), enter the sandblasting machine with the belt, after which they are subjected to heat treatment in the oven with a fixed hearth of $2.5 \mathrm{sqm}$. The technological flow is presented schematically in Figure 2.

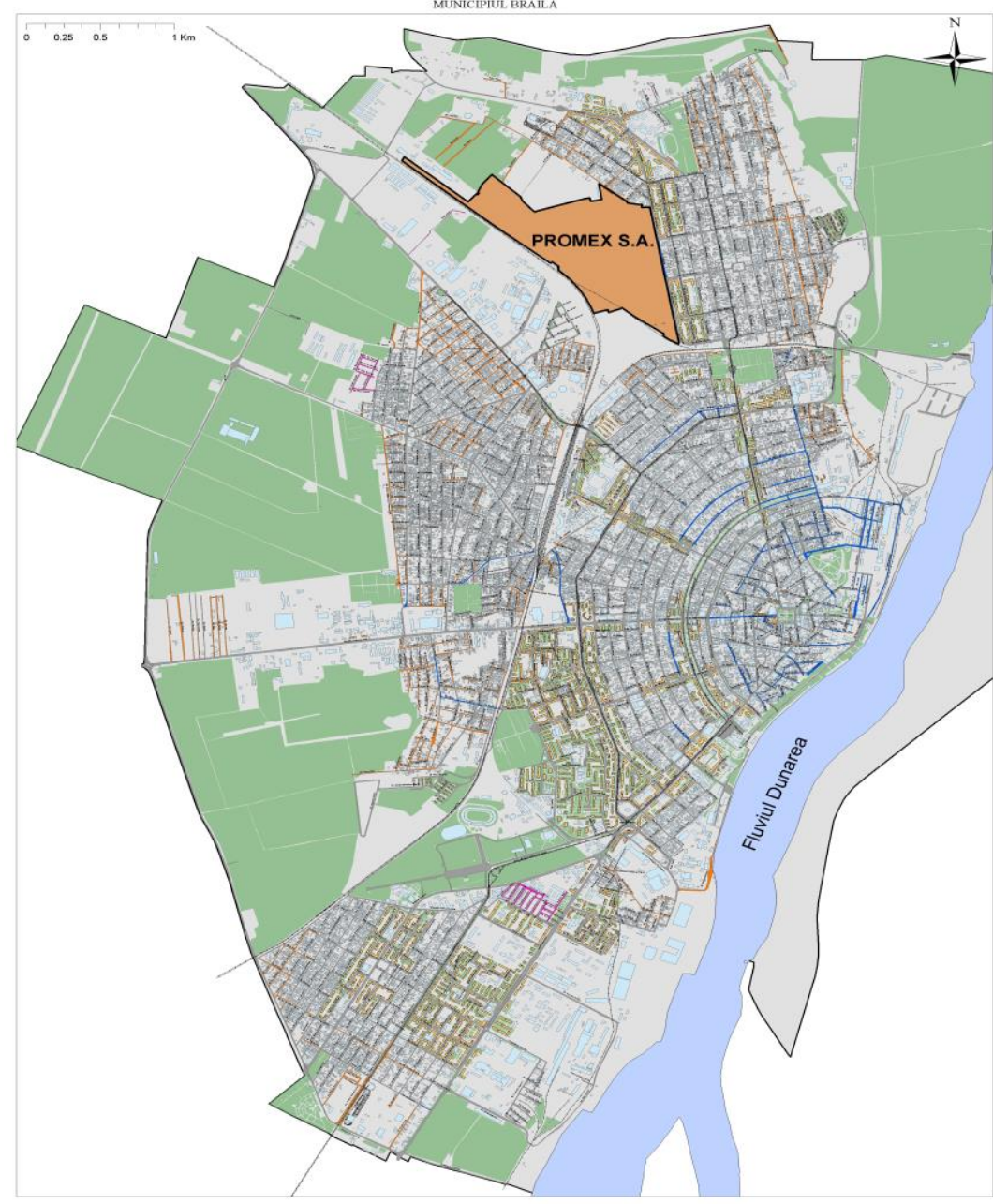

Fig. 1. Location of S.C. PROMEX S.A. Brăila

Table 1. Organization of production

\begin{tabular}{|c|c|c|}
\hline Number & Industry sectors & Finished product \\
\hline 1. & $\begin{array}{l}\text { Steel processing line: use fills in operation: } 2 \text { electric ovens with arc } \\
\text { of } 3 \mathrm{t} \text { /oven / charge and } 1 \text { oven of } 5 \mathrm{t} / \text { charge }\end{array}$ & Liquid steel \\
\hline 2. & The casting line consists of 3 casting areas & \multirow[b]{3}{*}{$\begin{array}{l}\text { Cast steel semi-finished } \\
\text { products }\end{array}$} \\
\hline 3. & Debating area, cleaning, sandblasting & \\
\hline 4. & $\begin{array}{l}\text { Heat treatment area installations in operation: } 1 \text { heat treatment } \\
\text { furnace with movable hearth of } 40 \mathrm{sqm} \text { and } 1 \text { furnace with fixed } \\
\text { hearth of } 2.5 \mathrm{sqm}\end{array}$ & \\
\hline 5. & $\begin{array}{l}\text { Casting line for special parts - for special parts steel/cast iron is made } \\
\text { in } 3 \text { electric induction furnaces, } 250 \mathrm{~kg} \text { each }\end{array}$ & $\begin{array}{l}\text { Special steel/cast iron } \\
\text { parts }\end{array}$ \\
\hline 6. & Shaping wood & Wooden models \\
\hline
\end{tabular}




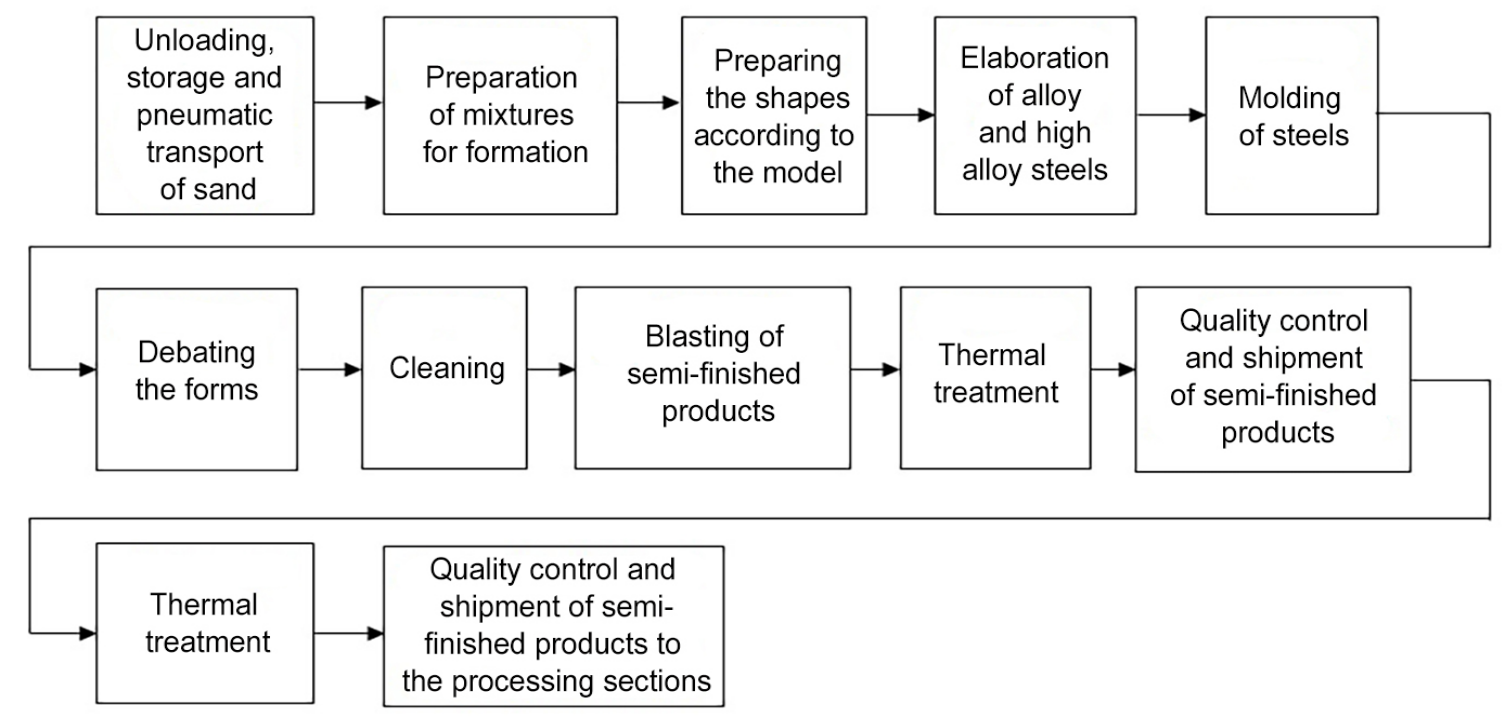

Fig. 2. Technological flow - Steel foundry

The activity of the Steel Foundry results in emissions in the form of sedimentable dusts, flue gases from combustion processes from heat treatment furnaces and flue gases from steel melting furnaces. Within the steel foundry, on the steel elaboration line are used 2 electric arc furnaces, each with a capacity of $3 \mathrm{t} /$ charge and 1 furnace with a capacity of 5 t/charge. Each furnace is provided with a hood located above the respective furnace, which partially captures the gaseous emissions $\left(\mathrm{NO}_{\mathrm{x}}, \mathrm{CO}_{2}, \mathrm{CO}\right)$ and the dust released as a result of the melting processes and from the evacuation of the molten steel. In the case of the special foundry, 3 electric induction furnaces of $250 \mathrm{~kg}$ each are used. The duration of a cold charge is about $1.5-2 \mathrm{~h}$, after which the duration of the charges decreases to $1.5 \mathrm{~h}$. As in the case of electric arc furnaces, induction furnaces are not used at the same time, due to the need to maintain a spare furnace.

Emissions in the form of sedimentable dust from the smelting of metals from the steel foundry and from electric furnaces ( 2 furnaces of $3 \mathrm{t} / \mathrm{charge}$ and 1 furnace of $5 \mathrm{t} / \mathrm{charge}$ ) are captured by a hood located above each furnace. The 3 hoods are connected to a centrifugal fan, which flows directly into the filter, where the filtration takes place. For air protection the installations are provided with local and general ventilation installations.

The flue gases, containing $\mathrm{CO}$ resulting from the electric and heat treatment furnaces (operating with methane gas) are evacuated through individual chimneys provided with nozzles for measurements.

The Gas Probe IAQ analyser was used to determine the amount of CO. The Gas Probe is one of the most accurate portable gas detectors. Suspended particles were measured using the HUZ-DUST HD-
1100 analyser. HAZ-DUST is a portable particle reader that uses infrared electromagnetic radiation to examine particles. The examination method is well known as light scattering.

Carbon monoxide (CO) and Suspended particles were determined between 2016-2019 at the following locations:

- Heat treatment oven $40 \mathrm{sqm}$;

- Electric oven 5 tons;

- Electric oven 3 tons;

- Special Foundry Line.

\section{Results and discussions}

In order to analyse the amounts of carbon monoxide and suspended dust, released into the atmosphere during 2016-2020, a set of measurements were performed annually. The monitoring of air pollutants has an essential role in the management of industrial emissions, including the choice of equipment and technologies.

The variation of the measured $\mathrm{CO}\left(\mathrm{mg} / \mathrm{m}^{3}\right)$ values was in the Heat treatment oven $40 \mathrm{sqm}$ area between $38.75\left(\mathrm{mg} / \mathrm{m}^{3}\right)$ and $11.11 \mathrm{mg} / \mathrm{m}^{3}$, between $43.5 \mathrm{mg} / \mathrm{m}^{3}$ and $7.12 \mathrm{mg} / \mathrm{m}^{3}$ in the Electric oven area 5 tons. In the 3 Tons electric oven area the values varied between $40.33 \mathrm{mg} / \mathrm{m}^{3}$ and $8.42 \mathrm{mg} / \mathrm{m}^{3}$, compared to the Special Foundry Line area where the values varied between $58.25 \mathrm{mg} / \mathrm{m}^{3}$ and $7.34 \mathrm{mg} / \mathrm{m}^{3}$.

In Figure 3 in blue we represented the 20 values obtained by measuring the $\mathrm{CO}$ emission in the Heat treatment area $40 \mathrm{sqm}$ and in red we presented the values obtained in the Electric oven area 5 tons.

The measurements in the 3 tons electric oven area were represented graphically in green and in 
orange the values in the Special Foundry Line area are represented. The measurements performed between 2016-2019 indicated the highest level of CO pollution in the area of Electric oven 5 tons and
Special Foundry Line, at each data collection measurements were performed, after calibrating the device.

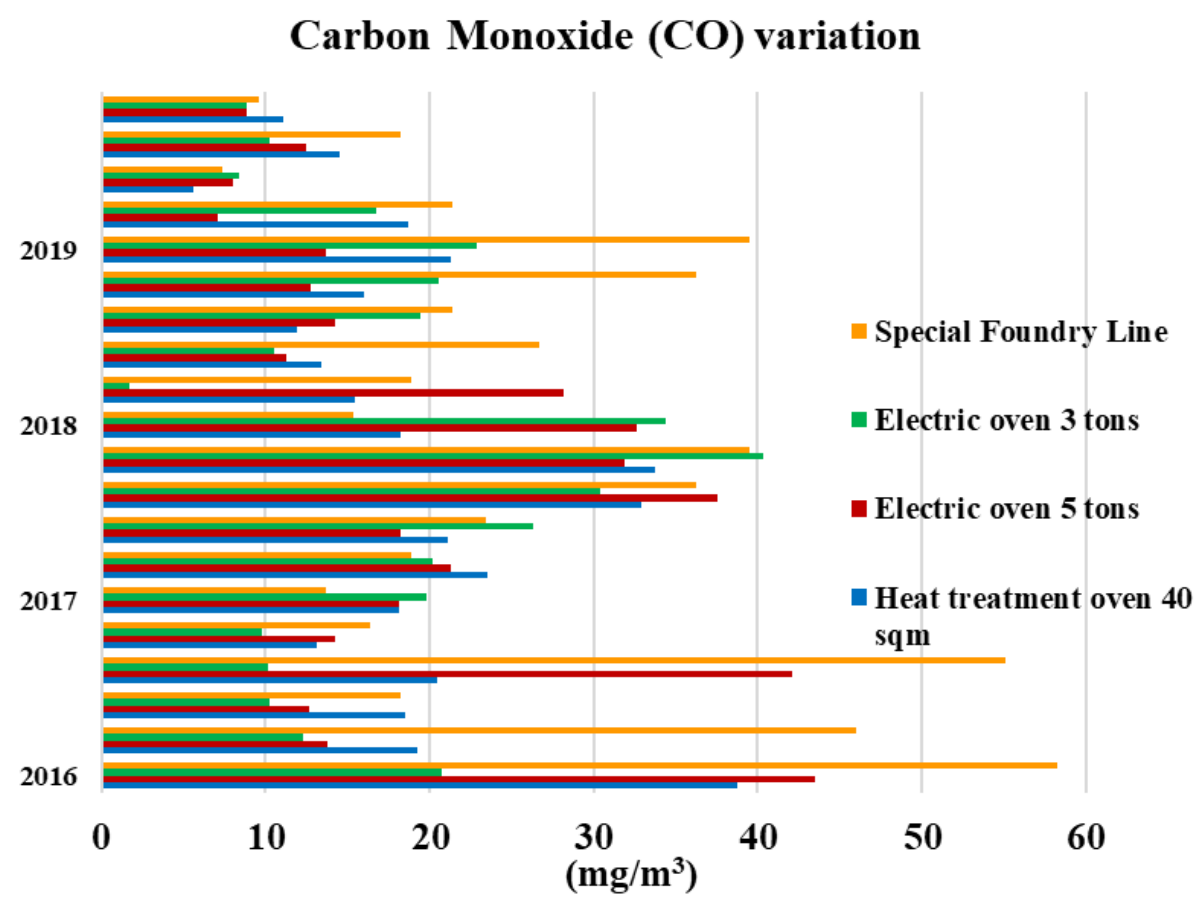

Fig. 3. Carbon Monoxide variation

\section{Carbon Monoxide}

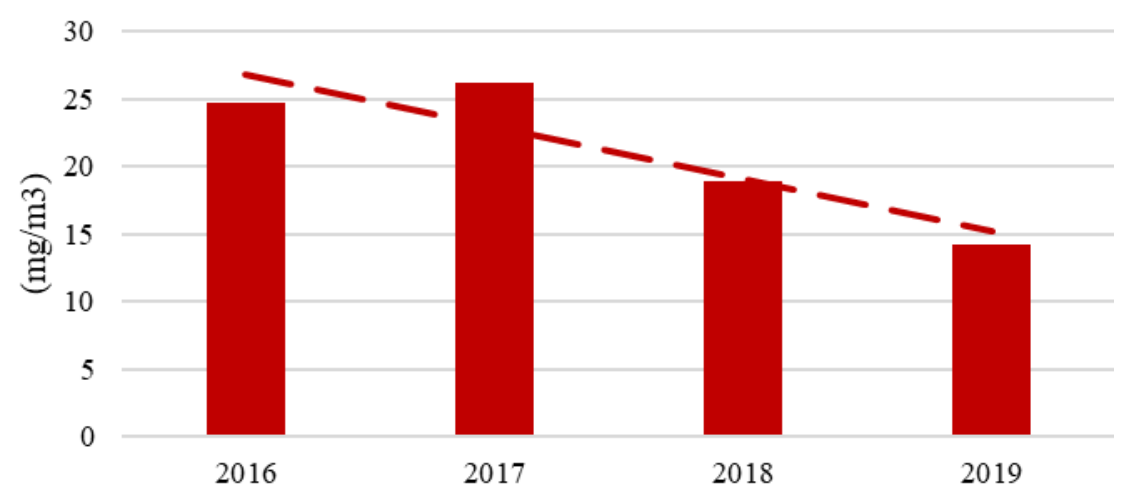

Fig. 4. Carbon Monoxide yearly average

The annual average of carbon monoxide for the four years, 2016-2019, was calculated in order to obtain a clear image of the pollutants emitted into the atmosphere by foundry steel sector of SC PROMEX SA.

It is obvious that the trend is decreasing (except for 2017), the quantities of carbon monoxide emitted varied from $24.67 \mathrm{mg} / \mathrm{m}^{3}$ in 2016 to $26.25 \mathrm{mg} / \mathrm{m}^{3}$ in 2017 and $14.22 \mathrm{mg} / \mathrm{m}^{3}$ in 2019.
The measured values of the Suspended particles $\left(\mathrm{mg} / \mathrm{m}^{3}\right)$ vary in the Heat Treatment Furnace area 40 sqm between $4.7 \mathrm{mg} / \mathrm{m}^{3}$ and $0.7 \mathrm{mg} / \mathrm{m}^{3}$, and between $6.05 \mathrm{mg} / \mathrm{m}^{3}$ and $1.97 \mathrm{mg} / \mathrm{m}^{3}$ in 5 tons Electric oven area. In the Electric Oven 3 tons area, were obtained values between $4.24 \mathrm{mg} / \mathrm{m}^{3}$ and $0.8 \mathrm{mg} / \mathrm{m}^{3}$, while in the Special Foundry Line area the values varied between $6.3 \mathrm{mg} / \mathrm{m}^{3}$ and $2.96 \mathrm{mg} / \mathrm{m}^{3}$. 
In Figure 5 the measured values for Suspended particles in the chimney, determined with the HUZDUST HD-1100 analyser, are presented. In purple we represented the values obtained after measuring the Suspended particles in the Heat treatment area 40 sqm, in red we presented the values obtained in the Electric oven area 5 tons. The measurements in the 3 tons electric oven area were represented graphically in blue and in green are represented the values in the Special Foundry Line area.

\section{Suspended particles variation}
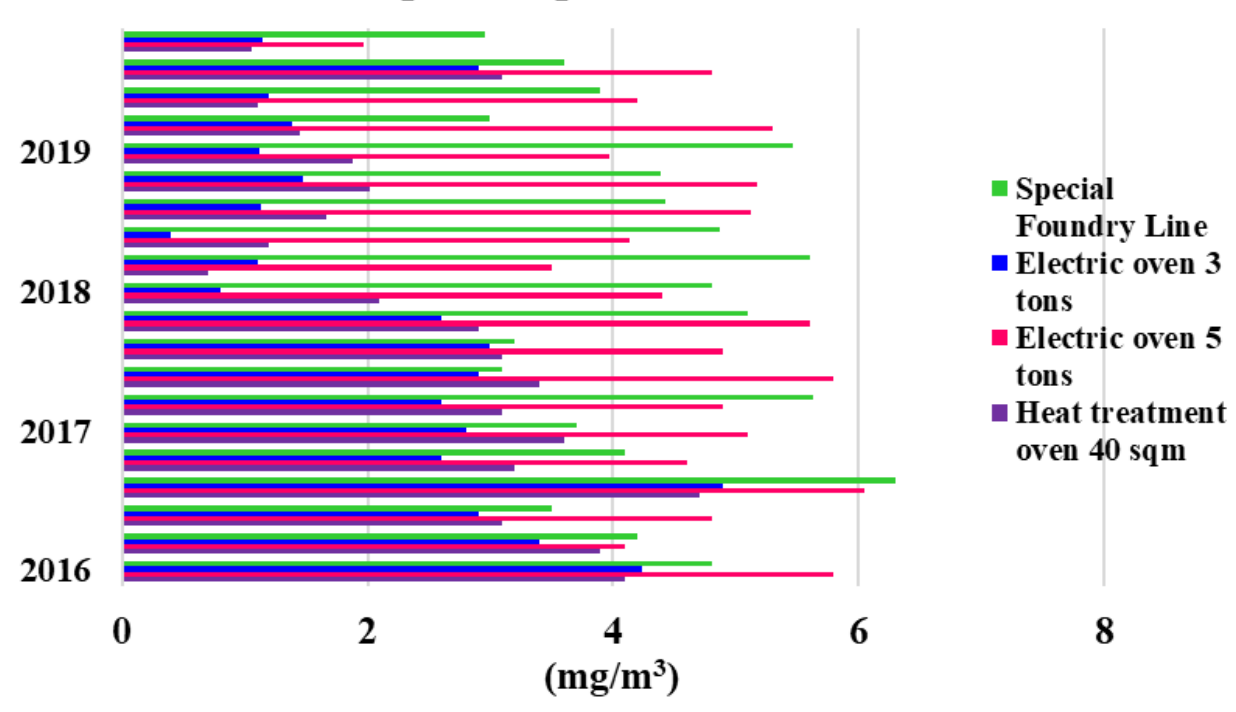

Fig. 5. Suspended particles variation

Suspended particles

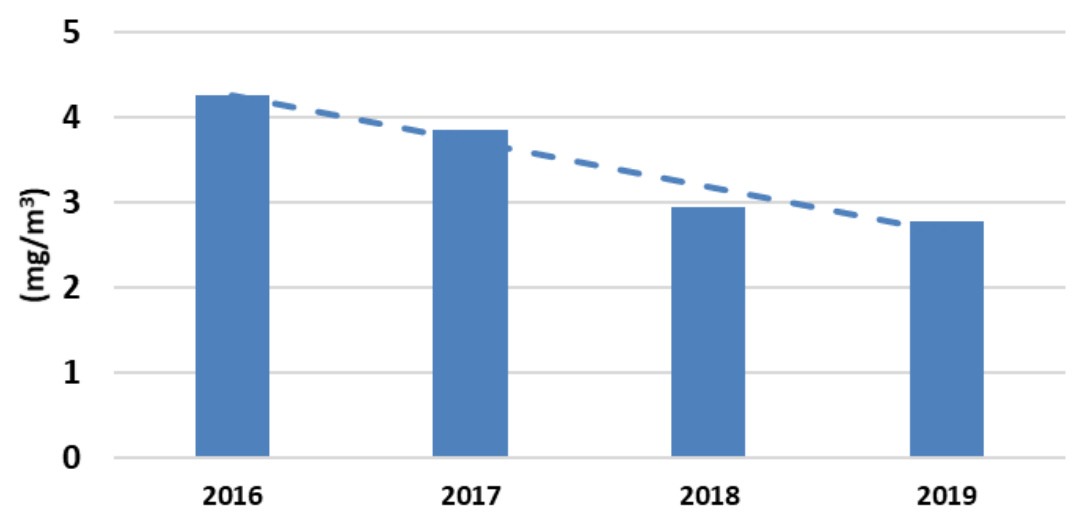

Fig. 6. Suspended particles yearly average

The yearly average of the amounts of suspended particles is a very precise method that allows us to observe the trend of variation of this pollutant.

As in the case of carbon monoxide and suspended powders, they also have a decreasing trend, with values ranging from $4.26 \mathrm{mg} / \mathrm{m}^{3}$ in 2016 to $2.77 \mathrm{mg} / \mathrm{m}^{3}$ in 2019 .

\section{Conclusions}

If we analyse the variation of the two pollutants: carbon dioxide and suspended particles only from the point of view of environmental protection, we can say that the situation is a good one because the amounts of pollutants eliminated in the atmosphere are decreasing. More specifically, in the case of carbon monoxide emissions have been reduced with 12.03 $\mathrm{mg} / \mathrm{m}^{3}$ that represent $30 \%$, comparing with suspended particles emissions that have decreased by 1.49 $\mathrm{mg} / \mathrm{m}^{3}$, which represents $22 \%$.

In the analysis of the technological flow/process, no risks were identified that could generate environmental pollution. It is obvious that the pollution with suspended particles in the areas of 


\section{THE ANNALS OF "DUNAREA DE JOS" UNIVERSITY OF GALATI \\ FASCICLE IX. METALLURGY AND MATERIALS SCIENCE \\ $\mathrm{N}^{\circ} .2$ - 2020, ISSN 2668-4748; e-ISSN 2668-4756 \\ Article DOI: https://doi.org/10.35219/mms.2020.2.08}

Electric oven 5 tons and Special Foundry Line is higher compared to the area's Electric oven 3 tons and Heat treatment oven $40 \mathrm{sqm}$.

Unfortunately, if we talk about the quantities of materials produced, they have decreased significantly, so as a conclusion the decrease of the quantities of pollutants is the effect of the decrease of the production of this commercial company and not of the investments in high-performance equipment.

\section{References}

[1]. Stefana E., Cocca P., Marciano F., Rossi D., Tomasoni G. A., Sustainability, 11, 7245, 2019.

[2]. ***, International Organization for Standardization. ISO 14001: Environmental Management Systems-Requirements with
Guidance for Use, International Organization for Standardization: Geneva, Switzerland, 2015.

[3]. Patange G., Khond M., Eur. Sci. J., 9, p. 241-252, 2013.

[4]. Dilip A., Tatsutani M., SAPI EN. S. Surveys and Perspectives Integrating Environment and Society, no. 2.1, 2009.

[5]. Zheng X., Ranran W., Richard W., Can W., Edgar G. H., Nature Geoscience, 11 (4), 269, 2018.

[6]. Fayomi O. S., Ayoola A. A., Morounfoluwa J., Akinwumi I. I., Published under licence by IOP Publishing Ltd IOP Conference Series: Materials Science and Engineering, vol. 640, no. 1, 2019.

[7]. Wang Y., Ying Z., Lu S., Xiangyu L., Lei D., Chengwen W., Tianyou H., Environmental Science \& Technology, 45 (15), p. 6539-44, 2011.

[8]. Pal P., Girish S., Abhishek N., Sanjeev S., Journal of Cleaner Production, 16 (12), p. 1264-74. https://doi.org/https://doi.org/ 10.1016/j.jclepro.2007.06.021, 2008.

[9]. Olmez G. M., Dilek F. B., Karanfil, T., Yetis U., J. Clean. Prod., 130, p. 195-201, 2016. 